\title{
The End of Scholarly Bibliography: Reconceptualizing Law Librarianship ${ }^{*}$
}

\author{
Robert C. Berring**
}

The death of Professor Morris L. Cohen raises the question of the future of scholarly bibliography. Has the information revolution with its digitization of data and its facile search engines transformed what once was a respected aspect of scholarship into a pursuit so specialized as to be seen as an antiquarian endeavor? In conjunction with this query, the history and status of law librarians is critically examined.

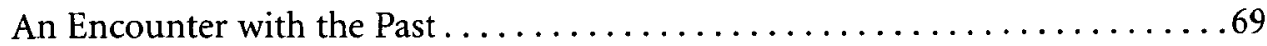

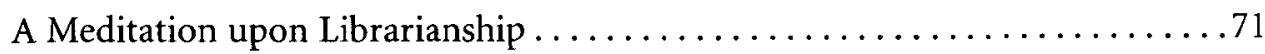

Acquiring Information. . . . . . . . . . . . . . . . . . . . 72

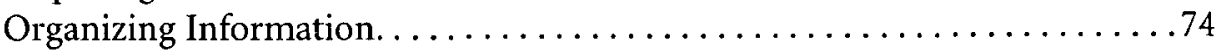

The Great Scholarly Bibliographers. . . . . . . . . . . . . . . . . 75

Law Librarians as Scholars . . . . . . . . . . . . . . . . . . . . 76

The Tao of Law Librarians: A Delayed Response to Professor White . . . . . . 78

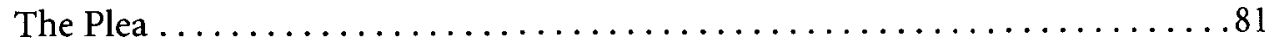

I1 The death of Morris L. Cohen serves as an important landmark for law librarianship in two senses. In the realm of the academy, it is a harbinger of the end of the age of the great bibliographer. Where once the academic community in general, and librarians in particular, paid special homage to those who gathered, described, and made accessible bits of three-dimensional information, such efforts are now becoming the sole province of the antiquarian. In the realm of the law library, Morris's passing raises some serious questions about the identity of the profession and of law librarians as scholars. Neither development is one that comforts me, but they must be recognized. It may be time to rethink the dynamics of the profession of law librarianship.

\section{An Encounter with the Past}

I2 When I went to work at the Harvard Law Library as Deputy Director in the fall of 1978, Morris, then the Law Library Director, gave me a tour of the Langdell

* (c) Robert C. Berring, 2012. I wish to thank Dean Rowan of the Berkeley Law School staff for helpful comments and Ian McConnaha, Berkeley Law School class of 2012, for his research assistance. All mistakes, and all opinions, are my own.

** Walter Perry Johnson Professor of Law, University of California, Berkeley School of Law, Boalt Hall, Berkeley, California. 
Library. This was a tour of the old incarnation of Langdell Hall, before the rebirth of the facility as a modern entity. An honest assessment would have been that the library was a shambles. There were pockets of stacks tucked in unlikely places, with many a surprise to be found therein. The technical services area contained tables filled with stacks of books, years' worth of volumes that had never been processed. There were diversions everywhere. The library exemplified the challenges of a universe of information built of paper.

q3 On the level where the bound volumes of Supreme Court records and briefs were shelved, there was a set of offices. This was the domain of emeritus faculty, along with the inimitable Professor Charles Donahue, ${ }^{1}$ who relished having a corner office in the oldest area of the stacks. We paused by one open door, and Morris took the opportunity to introduce me to Professor Sam Thorne. ${ }^{2}$ Professor Thorne had taken emeritus status at that point, but he was still at work. Other than his pleasant, if distracted, good manners, three things struck me about Professor Thorne. One was that he only read by natural light. He told me that when the sun no longer provided sufficient illumination, it was time to stop reading. There is something very pleasing about this thought, and it seemed to fit with Thorne's subject matter quite well. The second thing that impressed me was that he was spending his retirement years working on his masterful translation of Bracton. ${ }^{3}$ Seeing someone devoting his life to working through these ancient, puzzling volumes impressed me to no end. There was an intellectual purity to the endeavor. I was still naive about scholarship in 1978, and I found it amazing that a man would devote much of his adult life to working with such ancient materials, to bringing them under control. The third thing that amazed me: Morris informed me that Thorne was a former law librarian.

I4 Though I had looked into the history of law librarians a bit, I had never heard that Thorne had served as one of our own. ${ }^{4} \mathrm{He}$ did not define himself as a law librarian. Indeed, Morris counseled me that I should never mention it to him. ${ }^{5}$ For this reason, Thorne stands astride both of my areas of inquiry in this essay. His work for the Selden Society over the years, carefully studying and annotating the Yearbooks and his work in the field of legal history as the translator of Bracton ${ }^{6}$ are

1. Charles Donahue epitomized the world of scholarship discussed in this essay. He was not confident of the library's ability to catalog material to his standards, so he maintained his own card catalog in his office. He currently holds the Paul Freund Chair at Harvard Law School.

2. Samuel Thorne lived from 1907 to 1994. His obituary appeared in the New York Times of April 9, 1994. Samuel E. Thorne, Legal Historian, 87, N.Y. TimES, Apr. 9, 1994, at 11.

3. BRacton on the LaWS And Customs of England (Samuel E. Thorne trans., 1968-1977).

4. Though almost a decade has passed since I left the directorship of the law library at Berkeley to assume the position of Interim Dean and from there moved into a full-time faculty position, I will always consider myself a member of the profession of law librarianship.

5. Thorne's New York Times obituary, cited supra note 2, makes no mention of his having served as a law librarian. It is noted in the dagger footnote of his earlier writings and is noted in passing in some assessments of his work, but Thorne did not identify himself as a librarian. Morris Cohen's observation aside, I never heard of it. It is not noted in his festschrift. See ON THE LAWS AND CUSTOMS of England: Essays in Honor of Samuel E. Thorne (Morris S. Arnold et al. eds., 1981).

6. Thorne's work translating Bracton has been much celebrated. "Occasionally we get lawyers who, like Maitland, bridge the gap between authority and evidence. None has done so with greater or easier eminence than Professor Samuel E. Thorne." DeLloyd J. Guth, Samuel E. Thorne and Legal History in Law Schools, 80 MiCH. L. Rev. 765, 767 (1982). 
examples of the careful bibliographic scholarship that was once the crown jewel of academic librarianship in general and law librarianship in particular. ${ }^{7}$ Seeing him sitting in his office that day in 1978, I was looking at the embodiment of traditional scholarship. The fact that Thorne had served both Northwestern and Yale as law librarian impressed me as well.

I5 The scene was made more remarkable by the presence of Morris Cohen. Morris resembled Thorne on both counts. His work on the Bibliography of Early American Law $(B E A L)^{8}$ represents the apex of the bibliographic scholar in the law. Like Thorne, Morris was carrying out detailed, meticulous work. Each of them elevated the scholarly enterprise. Morris was also a law librarian who was viewed by the world as a public intellectual, a scholar of note and gravitas. ${ }^{9}$ In one striking way, though, Morris Cohen and Sam Thorne were quite different. The former was renowned as a scholar-librarian; the latter had decoupled his status as a scholar from his work as a librarian. More on that point later.

I6 Standing in the same physical space with these two giants was a privilege the likes of which I fear will not be repeated. The age of the scholarly bibliographer is gone, and at the same time the role of the scholar-librarian is under siege.

\section{A Meditation upon Librarianship}

I7 Librarians traditionally performed four functions. First, they gathered materials. Second, they created records of the materials that were so gathered. As a part of this process they developed schemes for organizing information so that it could be retrieved. Third, they physically arranged and preserved the materials. Fourth, they distributed the materials to those who needed them. The importance of each function has varied over time. The third one, the design of shelving schemes that led researchers to serendipitous discovery, has waned as the stacks have become less and less the locus of research. Early in my career, I would shake my head in wonder when researchers exclaimed that they had gone into the stacks looking for one book and, by incredible good fortune, had found an even better book. I wanted to tell them that generations of the best minds in the field had labored to design a shelving pattern that would achieve just this end. This function is now filled by Google's algorithms, in a process even more mysterious to the user. The fourth function, which centers on circulating materials and providing reference service, is in the midst of profound change but will be put aside for the purposes of this essay. It is the first two functions that have special relevance here.

7. A listing of Thorne's publications can be found in ON the LaWs and Customs of EnGland, supra note 5, at 397.

8. Morris L. COHEN, Bibliography OF EARLy AMERICAN LAW (1998).

9. The lengthy obituary of Morris that appeared in the New York Times and the subsequent note about him by Lincoln Caplan on the editorial page of the same paper are a fine testimony to Morris's public persona. See Dennis Hevesi, Morris L. Cohen, 83, Leader Among Legal Librarians, N.Y. Times, Dec. 26, 2010, at A32; Lincoln Caplan, Morris Cohen, N.Y. TIMES, Jan. 7, 2011, at A22. 


\section{Acquiring Information}

q8 For millennia, the major challenge for librarians lay in gathering and preserving material. Libraries predate the printing press, and for centuries possessing manuscripts was an end, a powerful end, in itself. Legal information was no exception. The publication of legal materials was scattershot. Even after the development of mass printing and the growth of what we conceive of as the modern library, collecting legal materials was a challenge of the first order. ${ }^{10}$ The great librarians were book hunters. Explorer librarians like Eldon Revare James of Harvard traveled the world to find foreign legal materials. ${ }^{11}$ Relationships with publishers throughout the United States and Europe were crucial to great research libraries. Simply possessing legal monographs or state attorneys general reports, to say nothing of foreign gazettes, was the name of the game. Those boxes of unprocessed books that I saw at the Harvard Law Library had to some extent achieved their purpose: they were there. Once obtained they could be processed when resources became available.

I9 As the methods of the Industrial Revolution were applied to the production of books, gathering together materials from the common law world became less and less difficult. Foreign materials remained the province of the great research library, but the publication stream grew more and more straightforward. Impassioned concern about the overabundance of legal materials took center stage. Futurists began to realize that simply housing all of these objects would be practically impossible.

\$10 As the twentieth century wore on, a new technology offered a solution to this problem. If one could not possess the information, perhaps one could possess a microform copy of it. ${ }^{12}$ Though touted as the solution to all collection problems, especially those related to storage, microform materials were very hard to love. Nor did they truly solve the problem. Innovators like the Law Library Microform Consortium, the brainchild of the irrepressible Jerry Dupont, could make microfiche of public documents as palatable as possible, but one can make only the most ragged of purses from a true sow's ear. The thought of information that I need being accessible only through the daunting portal of a surly, never-quite-workingsmoothly microfiche reader still gives me the shivers.

10. MATThew BatTles, LibraRY: AN UnQUiet History (2003) presents a clear and informed history of the development of libraries.

11. For a marvelous appreciation of a forgotten law librarian, see Roscoe Pound's memorial to Professor James. Roscoe Pound, Eldon Revare James: An Appreciation, 42 LaW LiBR. J. 76 (1949). James was a law school dean and an adviser to the Prince of Siam before becoming a law librarian. He not only served as President of AALL in 1934-1935, he is quite likely the only law librarian to hold Siam's Order of the White Elephant. A tribute from Dean Pound, one of the preeminent legal scholars of the time, speaks volumes.

12. Microform, produced in the media of microfilm and microfiche, was once hailed as a solution to the problem of storing ever-expanding collections of three-dimensional objects. The rise and fall of microform materials is most entertainingly told in NICHOLSON BAKER, DOUBLE FOLD: LIBRARIES AND THE AsSAULT ON PAPER (2001). Baker felt that books and, especially, newspapers were being thoughtlessly thrown away. For all its failings, microform material is still held in large quantities by great research collections. 
\$11 The twentieth century also brought interdisciplinary materials into the collections of law libraries. No longer did the challenge lie in finding legal texts, it now lay in knowing how to choose texts from other fields that might be relevant to research. Serving current faculty was daunting enough; divining what future faculty members might require called for a combination of subject expertise and prophecy. The acquisitions librarian with a keen eye and an unerring sense of where legal research was headed emerged as hero. Budgets were always limited; choices were tough. In choosing what would enter the collection and therefore be held as a speculative part of law's intellectual heritage, librarians played a crucial role. Though they might resist the idea that they served as arbiters of taste and quality, in a world of limited resources, it had to be so. This model, built for information that existed in a three-dimensional format, persisted until almost the end of the twentieth century.

I12 Acquiring the right materials was the golden fleece for many years. If gathering material and holding it is the principal purpose of the enterprise, the library with the most volumes wins. In the 1980s I worked in law libraries that obsessed over volume count the same way that a law school dean in 2011 obsesses over the data points that feed into the U.S. News \& World Report rankings. In a world of books and serials in the form of paper and microform, bigger was undeniably better.

I13 The last decades of the twentieth century witnessed the rapid evolution of a new trend: information no longer appeared only in paper format. Like all good revolutions, the digital revolution grew from the bottom up. As those born before $1980^{13}$ came to terms with information in digital form, those born after that date grew up with it. The older generation can learn to use a smartphone or an iPad, we can read blogs and hook up our RSS feeds, but we are not of that world. Current law students and those coming up the pipeline behind them are. Members of the new generation do not hate information that is on paper, but to them paper is just another tool, one best avoided if possible. Any type of information they want to read or use is out there in the cloud. It comes directly to a snazzy device that can be held in one hand. A building that is filled with books hoids little appeal: the stacks can be creepy, the organization scheme mysterious, and the needed item not on the shelf.

I14 None of this is meant to imply that acquisitions librarians are no longer needed. We still live in the shadow of the world of print. The choice of what database subscriptions to buy or which materials to license remains crucial. But it is not the same. As more and more information, in a growing variety of formats, is free or is marketed directly to the user, the librarian's role as arbiter gets smaller and smaller. Even if the acquisitions function remains important, it is no longer how the profession can define itself.

13. I use 1980 as the line of demarcation, borrowing it from JoHN PALfReY \& URS GASSER, BorN DigiTAL 1 (2008). It is a soft boundary with exceptions on both sides, especially when one thinks globally. 


\section{Organizing Information}

Systems for organizing information must be designed with the user in mind, but sometimes overlooked is that the objectives and principles that undergird these systems represent a hypostatization of users' needs. The specifications ... that are embodied in these objectives and principles have been developed and refined over a period of 150 years.... [T] hey are more stringent than can be imagined by most users .... ${ }^{14}$

I15 Elaine Svenonius here writes in defense of carefully designed systems for organizing information. The methods that she discusses involve mediated information. For purposes of this article, mediated information is information that has been processed by a human intermediary who sorts, tags, and brings order to a mass of data. The data being organized does not have to be in the form of books or databases. Once a sufficient quantity of anything accumulates to the point that it cannot be retained and sorted in one person's memory, a system is needed. The systems that librarians have developed have an underlying intellectual structure based on decades of careful thought about how people use information.

I16 In the world of three-dimensional information, the organizing function of librarians was central. How can one make sense of all that one possesses? The great minds of librarianship were devoted to designing organizational schemes that kept the growing store of books and periodicals under control. Great figures like Sir Anthony Panizzi, Melvil Dewey, and Seymour Lubetzky strode across this stage. Consider the chutzpah underpinning the assumption that one could design a subject structure that provided a preexisting location for every book on every possible subject. Precoordinated universal systems of organization represented categorization and classification at the highest level.

I17 But efforts to organize information with care and precision in the predigital world could themselves add a layer of complexity to an already complicated structure. Think of the massive cataloging systems developed in the twentieth century. As the volume of information continued to grow, systems of control were stretched. Librarians sailed between the Scylla of accreted information and the Charybdis of organizing systems that had become so complex as to be nearly useless. When I taught graduate students at the School of Library and Information Studies at Berkeley in the mid-1980s, we spent several sessions coming to grips with the intricacies of the Library of Congress Subject Headings. If using such a tool is the province of graduate study, then that tool is no longer of use to the average library user. Only the initiates had a chance of successfully understanding the system. There was too much information, and the technical standards for navigating it were too high.

I18 Then, just when the whole enterprise was reaching the redline, technology came to the rescue. But the price of that rescue was the end of any hope of control by librarians. Organization now resides in a black box. The algorithms used by Google, Westlaw, and LexisNexis to connect the researcher with desired information are proprietary. Neither users nor librarians can evaluate them even if they

14. Elaine Svenonius, The Intellectual Foundation of Information Organization, at $\mathbf{x}$ (2000). 
want to. Furthermore, these new systems are not the products of enterprises devoted to determining through reflection objectively transparent, universal principles of thought. The parameters now used to judge the success of systems are speed and ease of use. The driving force is profit.

I19 There is no point in lamenting this development. The battle is over and mediation of information by librarians lost. When we teach Advanced Legal Research here at Berkeley Law School, we view it as a victory if we can persuade our students of the value of using indexes instead of Boolean searching. Our victories are fewer and fewer. Should we take comfort in the fact that WestlawNext and Lexis Advance may signal the demise of Boolean searching? If so, it is cold comfort.

\section{The Great Scholarly Bibliographers}

I20 In a sense, the great bibliographic projects also were efforts at control. If a trusted eye examined an item and described it with care, it would be forever part of the known world of information. The elevation of a work into the authoritative canon via the judgment of a scholar is a lovely distillation of the old world of cognitive authority. Each item in BEAL is a brick in a great structure, one that may need amending or supplementing but which need not be replaced. There will never be a $B E A L$ 2.0. The work has been done, and done to strict standards. Morris Cohen took care to describe exactly what he did and how he did it. The process is transparent, but more important, it was undertaken with care by a single, trustworthy individual.

T21 In legal research, students are taught to trust nothing. No fact should go unverified, no assertion be made without a footnote. If one wants to say that the sun rises in the east in a law review article, one had best drop a footnote to back up the statement. Nothing should be taken on faith. But with a tool like $B E A L$, the researcher does that very thing. Like finding a statement of positive law, once one has checked $B E A L$, there is no need to push beyond it. Experts may find problems with it, as Daniel Cohen so eloquently described, ${ }^{15}$ but all changes will be minor repairs to the great work. Like the Dude, a tool like BEAL abides. ${ }^{16}$

I22 The same reasoning explains Professor Thorne's work. Once his translation of Bracton was complete, in a format that showed both the original and his translation on facing pages, the work was done. Researchers trust him and they trust his work. There may be disputes about bits and pieces, but the work is done. It too abides.

I23 The current debate about Google Books and the use of metadata in the Google Books Library Project underscores how radically ideas about intellectual authority are changing. Books no longer have to exist in three dimensions. They can be scanned into digital form or simply produced that way in the first place. The algorithms behind the major search engines (as well as those of Westlaw and

15. Daniel A. Cohen, In Praise of Morris L. Cohen's Bibliography of Early American Law, 104 LAW LIBR. J. 25, 2012 LAW LIBR. J. 3.

16. The BiG LebowSKI (Gramercy Pictures 1998), a movie by the Coen Brothers, is referenced several times in this essay. One cannot explain the Dude; one must watch the movie. 
LexisNexis) operate in the ether. There is a system organizing the information, but it works behind the scenes and is the product of commercial enterprises. Can we trust these commercial enterprises as much as we trusted Morris Cohen, Samuel Thorne, and scholarly bibliographers like them ${ }^{17}$

I24 The mediated world where a bibliographer organized the works of the past, or a cataloger made contemporary works available by ordering them into comprehensible bits saved from the maelstrom of data, is gone. Libraries still produce catalogs, but they are digital, and they are searched by keywords and Boolean strings. Simply searching by author is an advanced search in many systems. Nor is today's researcher content merely to find information on where to access the desired item-he wants the item itself delivered to his computer with the click of a mouse. The days of the double or triple look-up that led one from one source to another are past. Embedded links are no longer novel; they are expected.

\$25 The modern researcher will not tolerate double look-ups, nor will he bow his head to an organizational scheme thoughtfully crafted by librarians. The irony is that this researcher is still using information that has been highly manipulated, but because the vendors have designed systems with simple, straightforward front ends, he will never notice. In this world, what one does not notice does not exist. The bubble thus created around the user may be seen as labor-saving assistance or as sinister manipulation. It may be a great convenience to have Amazon recommend books to me, but isn't it a bit troubling that it can do so ${ }^{18}$

I26 The inevitable conclusion is that the careful, methodical work of great bibliographers is a vocation being consigned to the past. It was tied to the threedimensional object, and it solved the problems and challenges of the era of the book. Trusting an authoritative mind has given way to the use of a great search engine. In that sense, BEAL stands as one of the last of its class. Like Sam Thorne's belief in reading only by natural light, the authoritative bibliography has become a shining artifact of history.

\section{Law Librarians as Scholars}

I27 While I worked at the Harvard Law Library, the university hired a new director of the university libraries. The previous director, Douglas Bryant, had been a librarian. It was his bad luck to serve in years of tough budgets and campus revolution. ${ }^{19}$ Nineteen seventy-eight was not a good time to be an administrator of any

17. The growing ability of commercial vendors to design systems that grow and customize search results based on the identity of the researcher represents a new set of concerns that lie beyond the scope of this essay.

18. Eli Pariser, The Filter Bubble: What the Internet Is Hiding from You (2011) presents this problem in sharp relief.

19. One of my most vivid memories of working as a student employee in the library was the day that Mr. Bryant put out a call for volunteers to surround the Union Catalog to prevent it from being destroyed by rioting students, who correctly viewed it as the heart of Harvard's intellectual treasure. Before you dismiss my thoughts about catalogs, keep in mind that I volunteered that day. I was prepared to defend the Harvard Union Catalog with my life. 
type in a university. Bryant was replaced by Oscar Handlin, an eminent historian. ${ }^{20}$ Professor Handlin called a meeting of all Harvard librarians.

T28 At that time Harvard's many libraries were decentralized, following the Harvard model of "every tub on its own bottom." Handlin, as university librarian, floated above the structure, but his power was vague. Harvard College had its own librarian; though she reported to Handlin, she had some autonomy. The law library was very much a part of the law school. Libraries affiliated with powerful parts of the university, such as law and business, had the power of their parent divisions behind them. But weak or strong, independence was jealously guarded. This sort of general conclave was unusual.

\$29 Handlin made two points that I remember vividly. One was that he was not a librarian and, though he was an avid library user, he knew nothing about how the materials that he used reached him. Thus it was our job to instruct him. He told us that his reputation would not be based on his performance as University Librarian; he would be remembered, if at all, as a historian. The ball was in our court as far as the library was concerned. I found this line refreshingly honest and full of potential. How well it worked out is a topic for another day.

I30 A second point made by Professor Handlin that day, though, is relevant here. He cautioned us that he did not see where the next generation of scholarlibrarians would come from. Libraries were becoming mechanized and routinized to such a degree that there was no room for scholars. His image of the great librarian was someone known outside of librarianship as a scholar of renown. Handlin's model librarian was one who produced works recognized as important by the academy. These scholars could do important work that mattered to the academy within the scope of being a librarian. Handlin noted that there were members of his generation who qualified (I thought of Morris), but he worried: where were the apprentices in training?

\$31 Handlin's remarks struck home for me that day, and they still resonate. The best work done by law librarians today is mainly channeled into writing about legal research and legal information. ${ }^{21}$ This is well and good, but it is limiting. The teaching of legal research has never taken center stage in the world of legal education. Most programs are taught by adjuncts and lecturers, and librarians are lucky to play a part. Even in those cases where they do play a direct role, involvement in the legal research program is not a path to glory. In many law schools, the librarians and the legal research instructors scramble for position at the foot of the law school table. All of this is wrong-headed, and I have, in the past, fulminated at the undervaluing of legal research instruction. ${ }^{22}$

20. Oscar Handlin, born in 1915, joined the Harvard faculty in 1939. He is a much honored and prolific author. See Paul Vitello, Oscar Handlin Dies at 95, Historian Who Chronicled U.S. Immigration, N.Y. TIMEs, Sept. 24, 2011, at D8.

21. Nancy P. Johnson, Should You Use a Textbook to Teach Legal Research?, 103 LAW LIBR. J. 415, 2011 LAW LiBR. J. 26, provides a fascinating history of law librarians writing legal research textbooks. Her footnotes are an excellent guide to further research in this area.

22. Robert C. Berring \& Kathleen Vanden Heuvel, Legal Research: Should Students Learn It or Wing It?, 81 LAW LIBR. J. 431 (1989), is a fine example of my fulminating on this topic. 
\32 Recent curricular reforms of the first year of legal education have, if anything, emphasized writing skills and problem solving over systematic legal research training. Much legal research training of American law students falls by default to the employees of Westlaw and LexisNexis, who bring the motivation of profit, to say nothing of prizes and 24/7 help lines, to the enterprise.

I33 Legal information offers a better opportunity for librarians to make a mark. The move to open access to information and the nested questions of information policy are at the cutting edge of the law in 2012. Law librarians are players in this game. Richard Danner of Duke has been at the forefront of the issue via the Durham Statement and his thoughtful writing. But even Professor Danner's scholarship is only on the periphery of the world outside of librarianship.

\34 John Palfrey, Director of the Harvard Law Library, is a player in the world beyond libraries, but is he a librarian? Just as Oscar Handlin was brought in to run the Harvard University Libraries with no library experience, Professor Palfrey came to the rescue of the Harvard Law Library in 2009. Unlike Handlin, Palfrey is a young scholar who works in a field closely related to the world of libraries. He is a scholar of intellectual property, a former head of Harvard's Berkman Center for Internet \& Society, who earned his tenured position at Harvard Law School on the basis of work done there. His experience, combined with his boundless energy and personal charisma, makes Palfrey the right person at the right place at the right time. He is involved with the very issues of information and access to it that sit the center of the discussion. But will his work be identified as that of a law librarian? Is he more Sam Thorne or Morris Cohen? Or is he neither? One thing seems certain-he is not a librarian who morphed into being a recognized scholar. Perhaps he is a scholar who came to save law librarianship. ${ }^{23}$

\section{The Tao of Law Librarians: A Delayed Response to Professor White}

I35 Law librarians belong to a conflicted profession. The relation between those who work in law firm, corporate, county, or court libraries and their colleagues in academic law libraries has never been a simple one, and this can be reflected in our feelings about the importance of the scholar-librarian to the profession.

23. In November of 2011 , as this article entered the final stages of the editing process, John Palfrey announced that he was resigning his position as Law Librarian, Vice Dean and Professor of Law at Harvard Law School in order to become Headmaster at Phillips Academy. Press release, Palfrey Appointed as the Head of School at Phillips Academy Andover, HaRv. Law ScH., http://www.law .harvard.edu/news/2011/11/14_john-palfrey.html. Though his motives for the decision are most likely complex, his move is coincidental with a reorganization of the Harvard University Library system which appears to pull the law library into the structure of the university library in a way unknown in the past. Libraries Announce New Organizational Structure, HARv. MAG., Sept. 28, 2011, http://harvardmagazine.com/2011/09/new-harvard-library -structure\#.TsmKfYKRsFk. Professor Palfrey's decision is a personal loss for the profession. If the Harvard reorganization lessens the potential for the Harvard Law Library to play a leadership role in the evolution of law librarianship, the loss is also an institutional one. In any case, I wished to use this eleventh hour footnote to acknowledge that the future of academic law librarianship will not be found in Cambridge, Massachusetts. 
\36 This, though, is not the place to set out a careful brief for maintaining a united profession. It seems obvious to me that academic law librarians need the innovation and reality-based dynamism of private law libraries, and that private law librarians, and law librarians from all other sectors of the profession, need the leadership and prestige of the academic members. Here, though, I want to address a different issue, partly to determine whether we have, or need, scholar-librarians today, and partly to redress the misimpression of law librarianship that the future researcher might glean from the literature.

I37 I began with an anecdote about Sam Thorne, the esteemed legal historian who sailed away from law librarianship without looking back. But Thorne's predecessor at the helm of the Yale Law Library, Frederick Hicks, managed to make his name as a scholar without abandoning his identity as a librarian. Hicks's classic work, Men and Books Famous in the Law, ${ }^{24}$ still sits on my desk. (His other works are a little further away on a shelf.) He was a scholar-librarian who wrote about legal research but who made a reputation that penetrated the wider universe of legal scholarship. Morris Cohen and a handful of his contemporaries did the same. Who will inherit the mantle?

q38 To date we lack a full history of law librarianship. We have Law Librarianship: Historical Perspectives, ${ }^{25}$ but that is a book written by law librarians for law librarians. The individually authored chapters present a great deal of information, but with no overarching narrative. Frank Houdek has traced the history of law librarianship for years, but his careful scholarship has stayed largely within the realm of law librarianship.

139 Probably the most influential article written about the history of law librarians, and certainly the one with the most powerful access to the general law school world, was G. Edward White's effort, Law Librarians, in Green Bag in 2007. ${ }^{26}$ Green Bag circulates among a wide range of influential readers, and Professor White is a scholar of the first order. Personally I am a great fan of his award-winning work. ${ }^{27}$ But despite my love of Green $B a g^{28}$ and my respect for Professor White, the article appalled me.

I40 When White went in search of the essential nature of law librarians, he initially identified two prevalent stereotypes. One was the sentinel, the figure who maintains control of the environment. For his example he drew upon the old chestnut, Marian the librarian from Meredith Wilson's The Music Man. For his second

24. Frederick C. Hicks, Men and Books Famous in the LaW (1921).

25. Law Librarianship: Historical Perspectives (Laura N. Gasaway \& Michael G. Chiorzzi eds., 1996). One chapter of this book, Reflections on Mentors, was written by me. Id. at 185. My mentors deserved and deserve better treatment.

26. G. Edward White, Law Librarians, 11 GREEN BAG 2D 81 (2007).

27. Professor White is a much honored author. Among many honors his books have received is the Coif Triennial Book Award, and he has been short-listed for a Pulitzer. His impressive accomplishments are set out on his web page. G. Edward White, VA. LAw, http://www.law.virginia.edu/lawweb /faculty.nsf/PrFMPbW/gew. His books Oliver Wendell Holmes, JR. (2006), PaTTERns OF AMERICAN Legal Thought (1978), and The american Judicial Tradition: Profiles of Leading American JUDGES (1976) sit on my shelf.

28. I am also on the Board of Advisers of the Green Bag, and have held that position since its first issue. Its editor, Professor Ross Davies of George Mason Law School, is one of my culture heroes. 
stereotype he chose the character of Inspector Javert from Les Miserables, with Javert cast as protector of the purity and integrity of an institution. While I could happily spend time dissecting these examples, I shall let them stand as markers for where the piece was headed.

I41 As the real-life analogue for Marian the librarian as well as for Inspector Javert, White chose the indomitable Professor Frances Farmer, longtime Director at the University of Virginia Law Library. While Farmer was a true original, whose forceful personality I had the opportunity to observe firsthand as a young professional, she was never the intellectual leader of the profession. Nevertheless, White put forward Farmer as the model of the law librarian who really was a librarian first and foremost.

I42 Though White described the evolution of the Harvard Law Library in some detail, and despite his discussion of the increasing responsibilities assumed by law librarians during the explosive change in legal education that began in the 1970s, he never turned to the idea of librarians as scholars. He noted no librarians who made a scholarly mark in the late twentieth century. There is no mention of Morris Cohen, Richard Danner, Tom Reynolds, Sharon Hamby O'Connor, Fred Shapiro, or any of another dozen names that pop into my mind, to say nothing of the preceding generation: Frederick Hicks, Arthur Pulling, William Roalfe, or Miles Price.

I43 The only possible exception noted is Professor Roy Mersky, pictured in the article astride a horse. There can be no debate that Mersky was one of the most important figures in twentieth-century law librarianship. ${ }^{29}$ But his claim to fame is based on his consummate skills as a manager and his writings on legal research, not on his reputation as a scholar. Consider the issue of Law Library Journal that you hold in your hands, or that now appears on your screen, and the praises from within and without librarianship for Morris Cohen. White's statement that "it is very rare these days to find a librarian who combines running a library with teaching and scholarship, as Mersky has" 30 shows very little knowledge of the profession. White must not have looked very hard. Was there nothing to find? Or have we kept it hidden?

I44 When it came to discussing those who have had notable careers as legal academics while also working in the field of librarianship, White mentioned only Preble Stolz and Sam Thorne. He dismissed Thorne's scholarship in legal history as being so obscurantist that Thorne was forced to enter the legal academy through

29. The much-honored Professor Mersky died in 2008. A fitting tribute can be found on the University of Texas School of Law web site. In Memoriam: Professor Roy M. Mersky, 1925-2008 (May 7, 2008), http://www.utexas.edu/law/news/2008/050708_mersky.html. Like the influential Professor Marian Gallagher of the University of Washington Law School, Professor Mersky is remembered as a mentor to many law librarians.

30. White, supra note 26 , at 95. 
the backdoor of law librarianship. ${ }^{31}$ He makes mention of Stolz's work on the California courts ${ }^{32}$ as justification for his being viewed as a legitimate scholar. ${ }^{33}$

I45 These are startlingly inapt examples. Stolz's role as a law library director resembled Oscar Handlin's appointment at Harvard. He was an academic who was drafted into watching the law library after the director left precipitously. He served until a real director was found. The law library at Berkeley was in such a sorry state in 1981 that each finalist for the position withdrew his or her name from the search. Thus poor Professor Stolz had to endure two years as acting director. And endure is the right word-he intensely disliked the job. Since in 1982 it was my good fortune to replace Stolz as director (under a new dean with a new commitment to supporting the library), I can personally testify that he would never have wanted to be called a law librarian. ${ }^{34}$

I46 Sam Thorne became a scholar by leaving librarianship behind. Though for a different reason than Stolz, he did not want the world to think of him as a law librarian either. This is the section where White could have discussed Morris Cohen and those like him. Instead he chose two almost bizarre examples.

147 Further cementing my bewilderment with the article, White wrote, “By the 1970s, the era of the non-lawyer librarian had passed, and the era of the Thornes and Stolzes was winding down." 35 To borrow a phrase from The Simpsons character Apu, I am not sure where to begin in telling you what is wrong with that sentence. Thorne had abandoned his vision of himself as a librarian by 1951. Stolz was acting director at Berkeley from 1980 to 1982. One situation resolved long before 1970; one does not occur until a decade after that date. The two gentlemen have little in common. Nor is the issue of nonlawyer librarians one that is at all settled.

I48 White's article so annoyed me that I decided that I was incapable of writing a reasoned response. In the past I have been intemperate on occasion. Though it may seem hard to believe, one could be embarrassed by what one did even before the advent of YouTube. But it is time to say something.

\section{The Plea}

I49 We must face the sad fact that the best scholarship in the field of library science was premised on the book. The organizational systems, the great bibliographies, the resplendent collections of material: each may have reached the end of its utility at the end of the twentieth century.

31. "Thorne's scholarly focus, research in the English yearbooks of the medieval period, was regarded as sufficiently obscurantist by the early twentieth-century law teaching market that he began his career as a librarian, and only later evolved into the role of full-time faculty member, scholar, and progenitor of English legal historians at American law schools." Id. at 91. Besides getting the time period wrong, this sentence manages to offend an entire carload of individuals working in a variety of fields. But perhaps I am too obscurantist.

32. See, e.g., Preble Stolz, Judging Judges: The Investigation of Rose Bird and the California SUPREME COURT (1981).

33. White, supra note 26 , at 91.

34. Full disclosure: he was also one of my law school professors. His antipathy to the law library profession is not a matter subject to dispute.

35 . White, supra note 26, at 95 . 
\50 If academic law librarianship loses its future Morris Cohens, if there are no librarians in the field who produce work that burns with that gemlike flame of elegance, much will be lost. The field has done a poor job of promoting its own. The egalitarian nature of the librarian bends us toward leveling, not stratifying. How else could a sophisticated academic like White end up with Sam Thorne and Preble Stolz as our intellectual exemplars? Yet we need leaders. If law librarianship does not have a major presence in the scholarly world, if there are no law librarians who are viewed by those outside the field of information science as leading lights, the profession as we know it may be entering its endgame. There is an old expression used by the air force: For every one up in the sky there are ten on the ground. Law librarianship needs a few up there in the sky.

\$51 The catch is that no one will make it into orbit doing what Morris Cohen did. Information in a tangible format is fading fast, and those who work with it are in danger of slipping across the border into the land of the antiquarian. Morris would gladly have assumed the moniker of antiquarian, but in the era of printed books, there was special honor in such work. That is no longer the case. In 2007, White found Thorne's work "obscurantist." What will they say in 2017?

\$52 Librarianship in general and law librarianship in particular must find a new identity, a new way of projecting its image. Perhaps the solution is to employ the model of John Palfrey. Professor Palfrey embraced his role as library director. He entered into the profession with enthusiasm and purpose. He does not have a library degree, but neither did Frederick Hicks. Law librarianship has evolved in the past. The rise of the tenure-track law library director in the late twentieth century and the rise of the dual-degree "lawyer-librarian" can serve as examples. If this is the case, the profession must unite behind young scholars who can lead academic law libraries. Rather than holding them at arm's length, the profession should embrace them. The battles over the role of libraries and legal information will continue over the next decade. Law librarianship will need champions. Such men and women will not be found in the stacks, or writing bibliographies. They may not have library degrees. Other segments of the profession may find them startlingly novel. But they may just save the day. One can only hope. 